\title{
Fractional excretion of electrolytes and paradoxical aciduria in dairy cows with left displaced abomasum ${ }^{1}$
}

\author{
João H. Perotta ${ }^{2 *}$, Júlio A.N. Lisbôa ${ }^{3}$, Priscila F.V. Pereira ${ }^{3}$, Rüdiger D. Ollhoff4, \\ Nilton Vieira ${ }^{5}$, Karina K.M.C. Faliban ${ }^{6}$ and Ivan R. Barros Filho ${ }^{2}$
}

\begin{abstract}
Perotta J.H., Lisbôa J.A.N., Pereira P.F.V., Ollhoff R.D., Vieira N., Faliban K.K.M.C. \& Barros Filho I.R. 2018. Fractional excretion of electrolytes and paradoxical aciduria in dairy cows with left displaced abomasum. Pesquisa Veterinária Brasileira 38(5):840-846. Departamento de Medicina Veterinária, Universidade Federal do Paraná, Rua dos Funcionários 1540, Juvevê, Curitiba, PR 80035-050, Brazil. E-mail: perotta@ufpr.br

The fractional excretion of electrolytes is used to assess renal function and interpret electrolyte and acid-base imbalances. Left displaced abomasum is a common disorder in dairy cows, which causes hypokalemic, hypochloremic metabolic alkalosis. There is limited information on fractional excretion of electrolytes in cows with displaced abomasum. This study aimed to measure the fractional excretion of sodium, potassium, and chloride and paradoxical aciduria in dairy cows with displaced abomasum. Blood and urine samples were collected from 30 dairy cows before and 24,48 , and $72 \mathrm{~h}$ after surgery. The cows were divided into two groups (G1: laparoscopy and G2: laparotomy) with 15 cows each. The concentrations of chloride, sodium, potassium, and creatinine were measured in serum and urine. Urinary $\mathrm{pH}$ and packed cell volume were measured. Fractional excretion of sodium, potassium, and chloride and urinary strong ion difference $[\mathrm{SID}]_{\text {urine }}$ were calculated using published formulas. Cows in both groups showed hypokalemic, metabolic alkalosis before surgery; however, hypochloremia was observed only in G2. Potassium concentration significantly increased 24,48 , and $72 \mathrm{~h}$ after surgery in G1 and 48 and $72 \mathrm{~h}$ after surgery in G2. There were no significant changes in fractional excretion of sodium, chloride, and potassium and urinary $\mathrm{pH}$ and [SID] $]_{\text {urine }}$ between treatments and time points. Paradoxical aciduria was observed before and $24 \mathrm{~h}$ following surgery in G1. Fractional excretion and urinary SID are valuable tools to understand hypochloremic, hypokalemic alkalosis in dairy cows with displaced abomasum, as well as paradoxical aciduria and return of abomasal flux.
\end{abstract}

INDEX TERMS: Electrolytes, aciduria, dairy cows, abomasal displacement, acid-base disturbance, laparoscopic abomasopexy, metabolism, abomasum, cattle, clinics.

RESUMO.- [Excreção fracionada de eletrólitos em acidúria paradoxal em vacas leiteiras com deslocamento de abomaso à esquerda.] A excreção fracionada de eletrólitos é calculada

\footnotetext{
${ }^{1}$ Received on June 9, 2017.

Accepted for publication on June 11, 2017

${ }^{2}$ Departamento de Medicina Veterinária, Universidade Federal do Paraná (UFPR), Rua dos Funcionários 1540, Juvevê, Curitiba, PR 80035-050, Brazil. *Corresponding author: perotta@ufpr.br, ivanbarf@ufpr.br

${ }^{3}$ Universidade Católica do Paraná (UCPR), Rua Imaculada Conceição 115, Prado Velho, Curitiba, PR 80215-901, Brazil. E-mail: ollhoff@gmail.com

${ }^{4}$ Departamento de Clínicas Veterinárias, Universidade Estadual de Londrina (UEL), Campus Universitário, Cx. Postal 10.011, Londrina, PR 86057-970, Brazil. E-mails: janlisboa@uel.br, pri_fajardo@yahoo.com.br

${ }^{5}$ Médico Veterinário Autônomo, Rua José Nunes de Souza 537, Arapoti, PR 84990-000, Brazil. E-mail: nilvie@brturbo.com.br

${ }^{6}$ Departamento de Medicina Veterinária Preventiva, Universidade Estadual de Londrina (UEL), Campus Universitário, Cx. Postal 10.011, Londrina, PR 86057-970.E-mail: kkflaiban@uel.br
}

para verificar a função renal e auxiliar na interpretação de distúrbios eletrolíticos e ácido-base. 0 deslocamento de abomaso à esquerda é frequente em vacas leiteiras, ocasionado alcalose hipoclorêmica e hipocalêmica. Há pouca informação na literatura sobre excreção fracionada de eletrólitos em vacas com deslocamento de abomaso. Este estudo objetivou mensurar a excreção fracionada de sódio, potássio e cloro e a acidúria paradoxal em vacas leiteiras com deslocamento abomasal. Amostras sanguíneas e urinárias foram coletadas de 30 vacas antes e 24, 48 e 72 horas após operação. As vacas foram divididas em dois grupos (G1: laparoscopia e G2: laparotomia) com 15 animais cada. As concentrações de cloro, sódio, potássio e creatinina foram dosadas no soro e urina. Mensurou-se pH urinário e o hematócrito. A excreção fracionada e diferença de íons fortes urinário $[\mathrm{SID}]_{\text {urina }}$ foram calculados utilizando fórmulas publicadas. Vacas de ambos os grupos apresentaram alcalose hipocalêmica antes da operação. 
Não houve alterações significativas na excreção fracionada de sódio, potássio e cloro, no pH urinário e na [SID $]_{\text {urina }}$ entre os tratamentos e momentos. Acidúria paradoxal foi observada no G1 antes e 24h após operação. A excreção fracionada e $[\mathrm{SID}]_{\text {urina }}$ são ferramentas importantes para interpretar a alcalose hipoclorêmica e hipocalêmica em vacas leiteiras com deslocamento de abomaso, como também a acidúria paradoxal e o retorno do fluxo abomasal.

TERMOS DE INDEXAÇÃO: Eletrólitos, acidúria paradoxal, vacas leiteras, deslocamento de abomaso, distúrbio ácido-base, laparoscopia abomasopexia, metabolismo, abomaso, bovinos, clínica.

\section{INTRODUCTION}

The fractional electrolyte excretion (FE) is the percentage filtered by the glomerulus that is not reabsorbed and is subsequently excreted in the urine (Lefebvre et al. 2008). Besides its usefulness in evaluating nutritional adequacy and treatment for metabolic disturbances, the FE assesses renal function, and in particular acute tubular necrosis, since the renal tubules reabsorb and secrete electrolytes (Espinel 1976, Ulutaş et al. 2003, Lefebvre et al. 2008). An increased FE indicates a decrease in the reabsorption or an increase in the excretion of an electrolyte (Neiger \& Hagemoser 1985). However, FE is rarely used in veterinary medicine due to inconsistency in measurements (Lefebvre et al. 2008). Additionally, FE in the dairy cow can be influenced by factors such as season (Itoh 1989), gestation, and lactation (Ulutaș et al. 2003), and variations in diet (Lefebvre et al. 2008).

Urinary strong ion difference $\left([\mathrm{SID}]_{\text {urine }}\right.$ ) is used to differentiate renal hyperchloremic metabolic acidosis from non-renal causes (Balsorano et al. 2016). Additionally, [SID $]_{\text {urine }}$ may help in our understanding of the mechanisms involved in paradoxical aciduria (Constable et al. 2009). During metabolic alkalosis, the kidneys increase excretion of sodium and potassium and decrease excretion of chloride (Masevicius et al. 2010). Cattle urinary $\mathrm{pH}$ is influenced by four independent variables including SID, the concentration of ammonium, carbonic gas, and the concentration of phosphate. A change in the [SID $]_{\text {urine }}$ for example, reflects a direct change in urine $\mathrm{pH}$ (Constable et al. 2009).

Displacement of the abomasum is a common disorder in dairy herds (Van Winden \& Kuiper 2003). Cows with a displaced abomasum develop hypochloremic, hypokalemic metabolic alkalosis, have an increased bicarbonate ion concentration and a base excess, while sodium concentration remains within normal reference values (Barros Filho 2002). Generally, urine $\mathrm{pH}$ is regulated by the blood $\mathrm{pH}$, as the kidney preserves the normal body $\mathrm{pH}$. When urine is alkaline, it is assumed that alkalosis developed because there is a reduction in the excretion of acid. When urine is acidic, it is assumed that acidosis developed because there is an increase in the excretion of acid. However, paradoxical aciduria generally develops in cows with a left displaced abomasum (LDA) and metabolic alkalosis due to increased hydrogen ion excretion (Gingerich \& Murdick 1975a).

Little information has been published regarding urinary strong ion difference, FE, and paradoxical aciduria in cows with a displaced abomasum. Paradoxical aciduria has been described in cows with metabolic alkalosis secondary to a displaced abomasum (Gingerich \& Murdick 1975a, Buscher \& Klee 1993) and intestinal obstruction (McGuirk \& Butler 1980). The purpose of this study was to describe the FE in cows with a left displaced abomasum and evaluate the effects of two techniques of abomasopexy and, consequently the return of abomasal, flux on FE and urinary $\mathrm{pH}$.

\section{MATERIALS AND METHODS}

This study was approved by The Animal Care and Use Committee of the Universidade Federal do Paraná (no. 056/13). Thirty Holstein-Friesian cows affected by left displaced abomasum were used in this research. The animals were from nine high-yielding dairy farms from the municipality of Arapoti (24 $09^{\prime} 28^{\prime \prime} \mathrm{S} 49^{\circ} 49^{\prime}$ $37^{\prime \prime} 0$ ), Paraná state, Brazil. The cows were kept in a free stall barn and the diet consisted of corn silage, commercial ration, and oat hay.

The experiment was conducted between February 2015 and April 2015. The LAD was diagnosed based in clinical examination and drop in milk yield. The treatment was performed up to $12 \mathrm{~h}$ after diagnosis

The cows were randomly distributed into two groups with 15 cows each. Animals in group 1 (G1) were treated using one-step laparoscopic abomasopexy (Christiansen 2004), while those in Group 2 (G2) were treated via right paralumbar fossa laparotomy and ventral abomasopexy (Baker 1976, adapted by Vieira).

The mean of days between parturition and LAD was 71.9 (from 5 to 390 days) in G1 and 65.3 (from 1 to 270 days) in G2. Additionally, one cow in G1 and seven cows in G2 were pregnant at moment of diagnosis of abomasal displacement.

Simultaneous blood and urine samples were collected before surgery and 24, 48, and 72h after surgery. Samples were collected in the morning. Blood samples were collected from the jugular vein in plain tubes, centrifuged at $1500 \mathrm{~g}$ for $5 \mathrm{~min}$, and the sera was harvested and stored in Eppendorf microtubes (Eppendorf AG, Hamburg, Germany). Urine samples were obtained by perineal stimulation into plastic scintillation vials, centrifuged, and the supernatant was used for analysis. Urine $\mathrm{pH}$ was measured using a pen type $\mathrm{pH}$ meter (pH-009, Shanghai Longway Optical Instruments Co. Ltd., Shanghai, China) immediately after sample collection. At the same time, urinary ketone bodies were detected using a urinary dipstick test (Medi-Test, Machery und Nagel GmbH \& Co. KG, Düren, Germany). Following sample collection, serum and urine samples were stored at $-20^{\circ} \mathrm{C}$ until the time of analysis. The samples were analyzed for creatinine $(\mathrm{Cr})$, sodium $(\mathrm{Na})$, potassium $(\mathrm{K})$, and chloride $(\mathrm{Cl})$. Creatinine was measured using an enzymatic-colorimetric method (Jaffé method) with a commercial test kit (Dialab Produktion und Vetrieb von chemisch, Neudorf, Austria) and an automatic analyzer (BS-200 Chemistry Analyzer, Mindray, Shenzhen, China). Sodium, potassium, and chloride ions were measured using an ion-selective electrode (Dimension, Siemens Healthcare GmbH, Munich, Germany). Packed cell volume was measured on EDTA tube using spun PCV in microcentrifuge tube.

The fractional excretion of $\mathrm{Na}, \mathrm{K}$, and $\mathrm{Cl}$ were calculated using the formula (Itoh 1989):

$$
F E e(\%)=\frac{U e \times \text { Scrx } 100}{\text { Se } x \text { Ucr }}
$$

where, $\mathrm{FE} e$ is the fractional excretion of a substance $e$; Ue is the concentration of substance $e$ in the urine; $e$ is the concentration of substance e in the serum; Ucr is the concentration of creatinine in the urine; and Scr is the concentration of creatinine in the serum.

Urinary Strong Ion Difference $\left([S I D]_{\text {urine }}\right)$ was calculated using the formula (Moviat et al. 2006):

$$
[S I D]_{\text {urine }}=\left(\left[\mathrm{Na}^{+}\right]+\left[\mathrm{K}^{+}\right]\right)-\left[\mathrm{Cl}^{-}\right]
$$

Normality of the data was tested using the Shapiro-Wilk test. Because most of the data were not normally distributed, the results for sodium, chloride, urinary $\mathrm{pH}$, and fractional excretion of sodium, 
potassium, and chloride were expressed as the median, first, and third interquartile ranges. A repeated measures ANOVA with ranks (Kruskal-Wallis test) was used to compare the results. When F was statistically significant, Dunn's test was applied to compare the means. Data for urinary SID, PCV, Base Excess, and blood potassium were normally distributed and were expressed as the mean \pm SD. Repeated measures ANOVA with two factors (time and treatment) was used to compare the results. When F was statistically significant, the Bonferroni test was applied to compare the means. Test results were considered significant for values of $P<.05$.

\section{RESULTS}

The mean \pm SD weight and age of the cows in G1 were $639.47 \pm 125.87 \mathrm{~kg}$ and $4.09 \pm 1.33$ years old respectively. The mean \pm SD weight and age of the cows in G2 were $618.73 \pm 88.55 \mathrm{~kg}$ and $4.25 \pm 1.83$ years old respectively.

Cows from both groups developed metabolic alkalosis before surgery demonstrated by significant increases in blood $\mathrm{pH}$, bicarbonate (data not shown), and base excess (Table 1, Fig.1). The metabolic alkalosis was characterized by hypochloremia in G2 and hypokalemia in both groups before surgery (Table 1 and 2, Fig.1). Cows from G2 were still hypokalemic $24 \mathrm{~h}$ following surgery. Mean serum potassium concentration significantly increased 24,48 , and $72 \mathrm{~h}$ after surgery in G1, and 48 and 72h after surgery in G2 (Table 1,
Fig.2). The median serum sodium concentration was within the reference interval and showed no significant differences between treatments and time points (Table 2, Fig.1).

Table 1. Mean $(\overline{\mathrm{X}})$, standard deviation (S) and $P$ value of potassium, base excess and hematocrit of 30 dairy cows with left displaced abomasum and treated by one-step laparoscopy (laparoscopy; 15 cows) and right flank laparotomy (laparotomy; 15 cows)

\begin{tabular}{ccccccc}
\hline \multirow{2}{*}{ Variable } & \multirow{2}{*}{ Time $(\mathrm{h})$} & \multicolumn{2}{c}{ Laparoscopy } & & \multicolumn{2}{c}{ Laparotomy } \\
\cline { 3 - 4 } \cline { 6 - 7 } & & Mean \pm S & P value & & Mean \pm S & P value \\
\hline Potassium & 0 & $3.36 \pm 0.7$ & & & $3.45 \pm 0.65$ & \\
& 24 & $4.12 \pm 0.45^{*}$ & $<0.01$ & & $3.78 \pm 0.14$ & \\
& 48 & $4.04 \pm 0.29^{*}$ & 0.01 & & $4.02 \pm 0.12^{*}$ & 0.018 \\
Base & 72 & $3.99 \pm 0.46^{*}$ & 0.04 & & $4.06 \pm 0.38^{*}$ & 0.008 \\
excess & 0 & $7.2 \pm 6.64$ & & & $8.73 \pm 8.37$ & \\
& 24 & $2.4 \pm 5.47^{*}$ & 0,01 & & $5.06 \pm 4.13^{*}$ & 0.04 \\
& 48 & $2.93 \pm 2.68^{*}$ & 0,02 & & $5.6 \pm 3.29^{*}$ & 0.045 \\
Hematocrit & 0 & $27.66 \pm 2.99^{*}$ & 0,03 & & $5.2 \pm 3.76^{*}$ & 0.015 \\
& 24 & $25.5 \pm 3.3$ & & & $27.6 \pm 3.9$ & \\
& 48 & $24.4 \pm 2.9^{*}$ & $<0.001$ & & $24.3 \pm 2.9^{*}$ & $<0.001$ \\
& 72 & $23.4 \pm 5.6^{*}$ & $<0.001$ & & $24.1 \pm 3.2^{*}$ & $<0.001$
\end{tabular}

* Differ from basal $(\mathrm{p}<0.05)$.
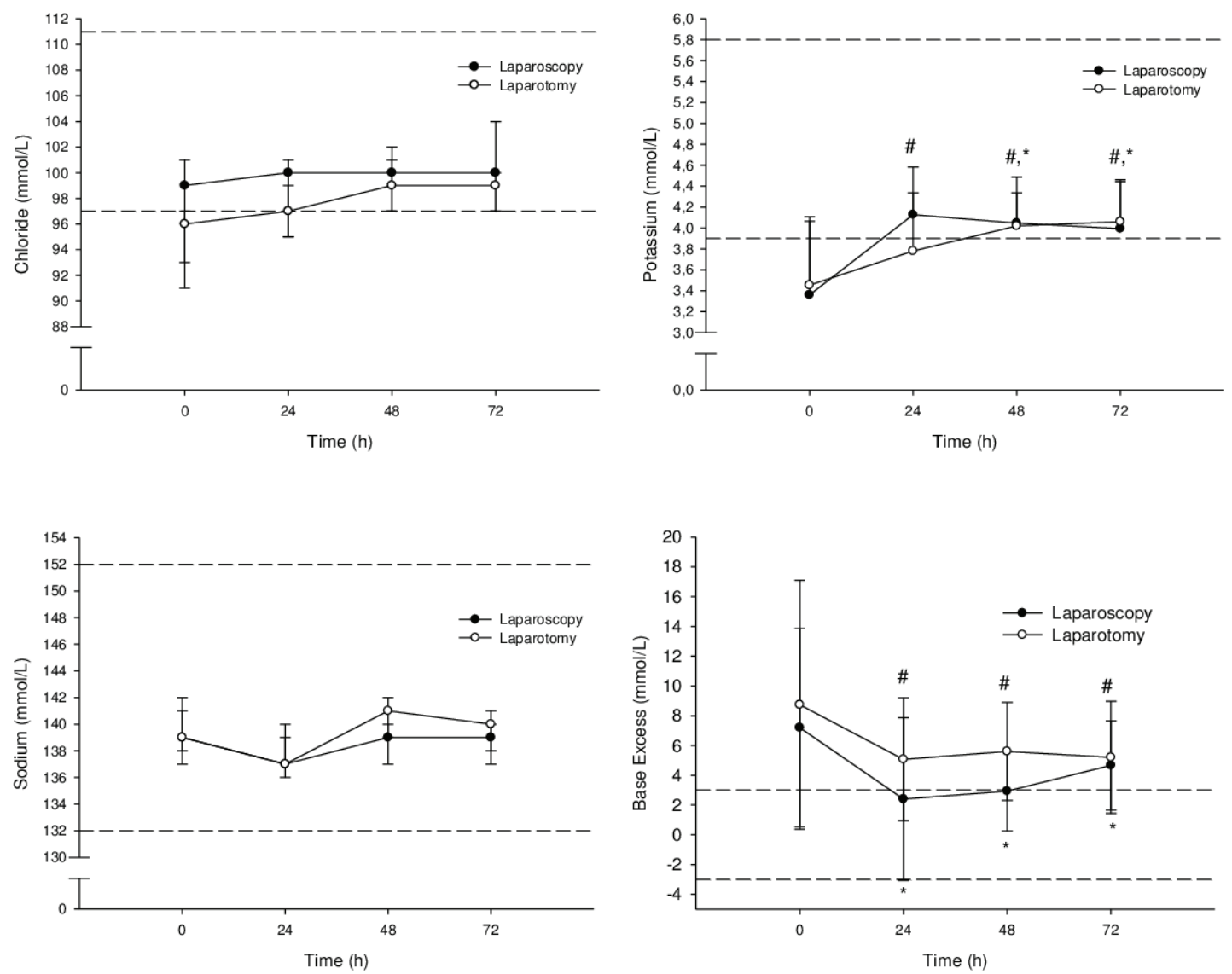

Fig.1. Serum chloride, sodium, and potassium concentration and Base Excess in cows with left displaced abomasum treated by one-step laparoscopic abomasopexy (laparoscopy, $\mathrm{n}=15$ ) or ventral abomasopexy via right paralumbar fossa laparotomy (laparotomy, $\mathrm{n}=15$ ). Dashed lines represent the upper and lower reference values. Data for chloride and sodium are expressed as the median (circle) and interquartile ranges (error bars). Data for potassium and Base Excess are expressed as mean \pm SD. \# Indicates a significant difference from baseline (Laparoscopy group). * Indicates a significant difference from baseline (Laparotomy group). 
Table 2. Median, 25th and 75th interquartile of chloride, sodium, urinary pH, urinary strong ion difference, fractional excretion of potassium, sodium, and chloride of $\mathbf{3 0}$ dairy cows with left displaced abomasum and treated by one-step laparoscopy (laparoscopy; 15 cows) and right flank laparotomy (laparotomy; 15 cows)

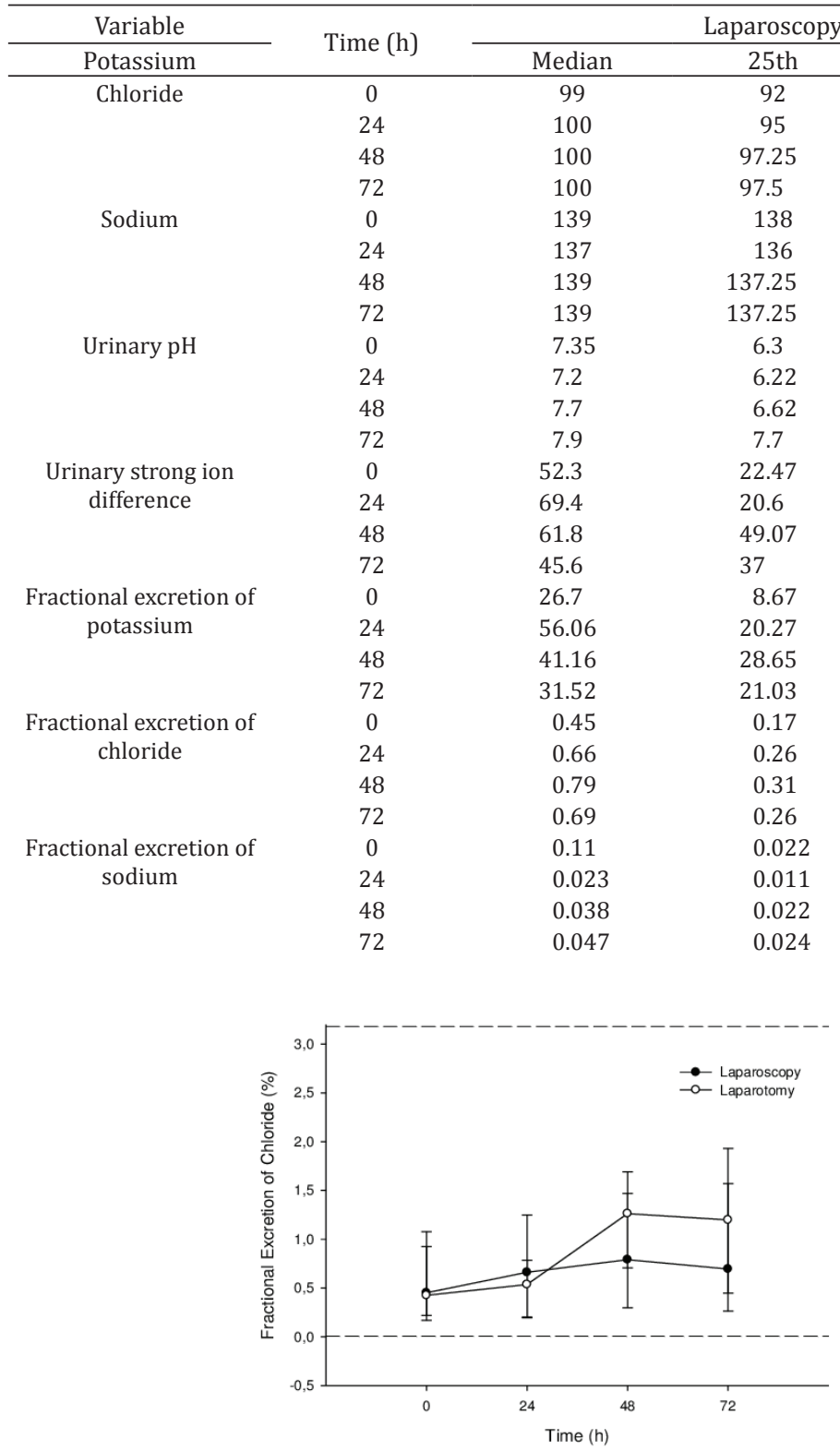

\begin{tabular}{|c|c|c|c|}
\hline & \multicolumn{3}{|c|}{ Laparotomy } \\
\hline 75 th & Median & 25 th & 75 th \\
\hline 100.75 & 96 & 93.75 & 97 \\
\hline 101 & 97 & 95.25 & 98.75 \\
\hline 101.75 & 99 & 97 & 101 \\
\hline 103.75 & 99 & 97.25 & 100 \\
\hline 141.5 & 139 & 137 & 140.75 \\
\hline 139.75 & 137 & 137 & 139 \\
\hline 140 & 141 & 139 & 142 \\
\hline 140 & 140 & 138 & 141 \\
\hline 7.6 & 7.9 & 7.3 & 8.3 \\
\hline 8.15 & 7.8 & 6.95 & 8.37 \\
\hline 8.17 & 8.3 & 7.82 & 8.5 \\
\hline 8.20 & 8.1 & 7.57 & 8.47 \\
\hline 64.65 & 78.5 & 33.17 & 115.2 \\
\hline 113.5 & 72.7 & 33.45 & 128.3 \\
\hline 110.4 & 105.4 & 90.57 & 140 \\
\hline 82.67 & 88.5 & 47.07 & 152.2 \\
\hline 65.82 & 22.49 & 9.49 & 45.35 \\
\hline 75.33 & 29.75 & 16.62 & 49.65 \\
\hline 64.75 & 52.37 & 38.95 & 65.66 \\
\hline 98.37 & 49.72 & 31.21 & 87.9 \\
\hline 1.06 & 0.42 & 0.23 & 0.89 \\
\hline 1.21 & 0.53 & 0.20 & 0.78 \\
\hline 1.42 & 1.26 & 0.73 & 1.63 \\
\hline 1.52 & 1.19 & 0.48 & 1.79 \\
\hline 0.31 & 0.23 & 0.017 & 0.54 \\
\hline 0.14 & 0.05 & 0.017 & 0.14 \\
\hline 0.13 & 0.11 & 0.061 & 0.7 \\
\hline 0.12 & 0.19 & 0.05 & 0.53 \\
\hline
\end{tabular}
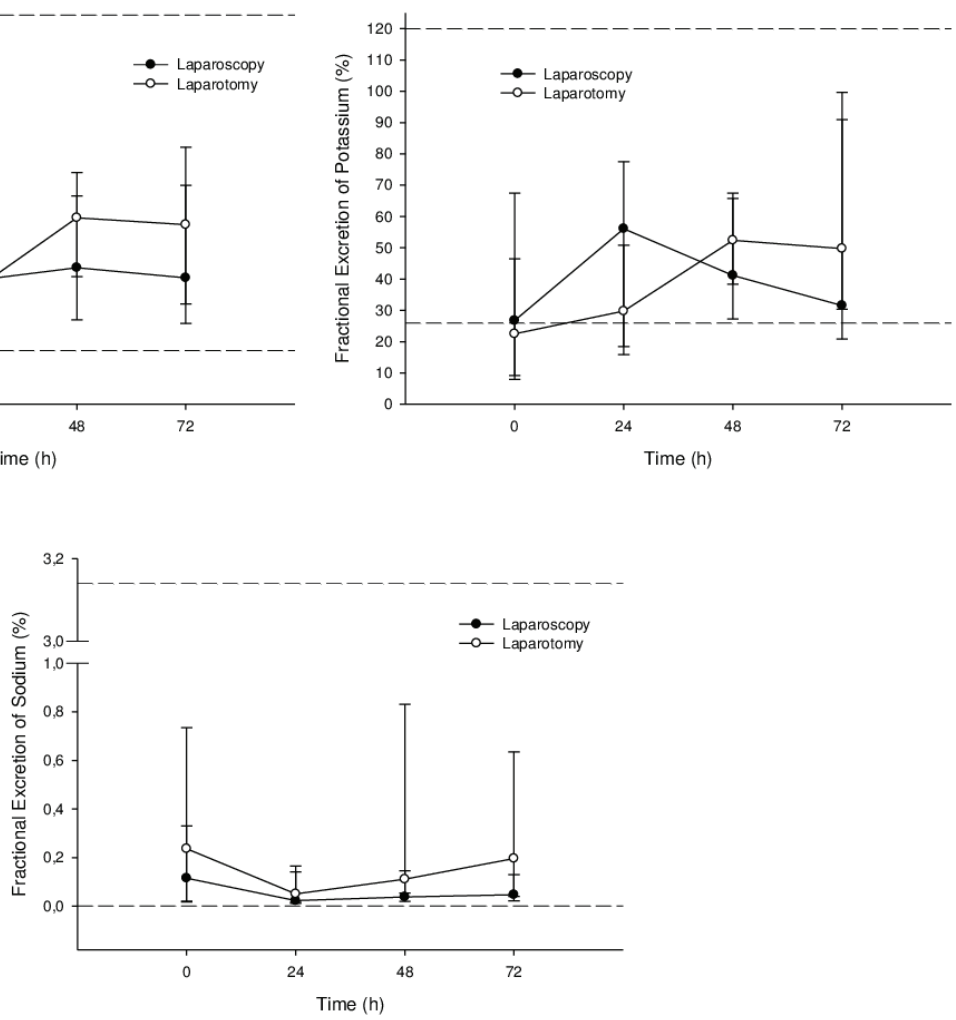

Fig.2. Fractional excretion of sodium, potassium, and chloride from cows with left displaced abomasum treated by one-step laparoscopic abomasopexy (laparoscopy, $\mathrm{n}=15$ ) or ventral abomasopexy via right paralumbar fossa laparotomy (laparotomy, $\mathrm{n}=15$ ). Circles show the median values and error bars show the interquartile ranges. 

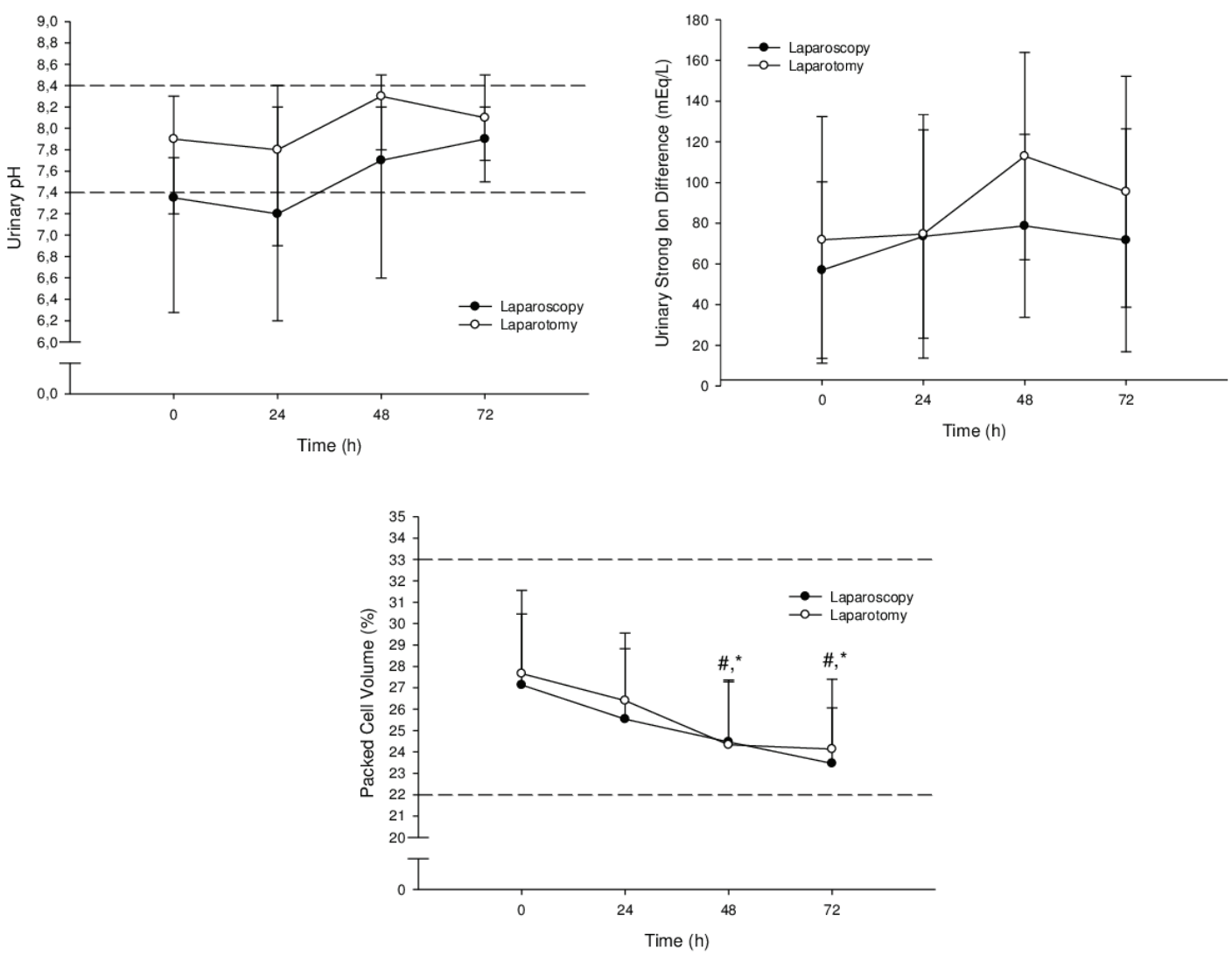

Fig.3. Urinary $\mathrm{pH}$, strong ion difference and packed cell volume in cows with left displaced abomasum treated by one-step laparoscopic abomasopexy (laparoscopy, $\mathrm{n}=15$ ) or ventral abomasopexy via right paralumbar fossa laparotomy (laparotomy, $\mathrm{n}=15$ ). Data for urinary $\mathrm{pH}$ is expressed as the median (circle) and interquartile ranges (error bars). Data for urinary strong ion difference and packed cell volume expressed as the mean \pm SD. \# Indicates a significant difference from baseline (Laparoscopy group). * Indicates a significant difference from baseline (Laparotomy group).

There were no significant changes in the fractional excretion of $\mathrm{Na}, \mathrm{Cl}$, and $\mathrm{Kand}$ in urinary $\mathrm{pH}$ and $[\mathrm{SID}]_{\text {urine }}$ between treatments and time points (Table 2, Fig.2 and 3). Fractional excretion of potassium was below reference values before surgery in G2 (22.5\% vs. 26.9\%; Fleming et al. 1992). Paradoxical aciduria was observed before and $24 \mathrm{~h}$ following surgery in G1. Despite being within the normal range, the PCV decreased significantly 48 and $72 \mathrm{~h}$ following surgery in both groups (Table 1, Fig.3).

\section{DISCUSSION}

This study measured the fractional excretion of sodium, potassium, and chloride and evaluated paradoxical aciduria in dairy cows with a displaced abomasum that were treated via two different surgical methods.

The kidney is vital in the body's control of sodium and chloride, as $80 \%$ of sodium is resorbed combined with chloride, and the remaining is exchanged for potassium or hydrogen, to maintain electroneutrality (Gingerich \& Murdick 1975b, Koch \& Taylor 1992). Renal control of Na and K are important for maintaining intravascular volume and cardiac physiology respectively, while renal excretion/ reabsorption of chloride is used in regulation of plasma acid-base status (Kellum 2000).

During hypochloremic, hypokalemic metabolic alkalosis, hydrogen is primarily reabsorbed with sodium to titrate the excess bicarbonate. However, the potassium is depleted promptly, and then the severe hypokalemic state induces reabsorption of potassium at the expense of hydrogen. This exchange increases the secretion of hydrogen ions by the kidneys, maintaining the alkalosis, and resulting in paradoxical aciduria (Gingerich \& Murdick 1975b, Koch \& Taylor 1992, DiBartola 2012).

In states of ineffective circulating volume, the kidneys retain bicarbonate in order to reabsorb sodium and maintain electroneutrality. If sodium was to be excreted, then the volume depletion would be exacerbated (Koch \& Taylor 1992). Dehydration and sodium depletion stimulate aldosterone secretion, which causes sodium reabsorption and renal excretion of potassium and hydrogen (Gardham 1970, Siow et al. 2009).

The acid-base status of the cows with left displaced abomasum included in this study was similar to that previously described in the literature. The normochloremia in G1 and mild hypochloremia in $\mathrm{G} 2$ could be explained by fast surgical intervention, generally within $12 \mathrm{~h}$ after the first clinical signs of LDA appeared, which prevented further deterioration of the acid-base imbalance.

In this study, paradoxical aciduria was observed only in G1 and before surgery (7.35 vs. 7.4-8.4, Buscher \& Klee 1993). While ketosis/ketonuria is not generally associated with aciduria (Gingerich \& Murdick 1975a), 66.37\% of cows 
in G1 showed ketosis and associated ketonuria, compared to $20 \%$ of cows in G2. This may explain the lower pH in G1, which has been previously discussed by Markusfeld (1987) and González et al. (2011).

Urinary SID has direct influence on the plasma concentration of chloride, since in hyperchloremic metabolic acidosis, chloride excretion is increased in order to lower the $[S I D]_{\text {urine }}$ and avoid hyperchloremia (Masevicius et al. 2013). Additionally, acidic urine is associated with a high urinary chloride concentration (Constable et al. 2009). The hypochloremic metabolic alkalosis status presented in cows with a displaced abomasum is characterized by an increase in [SID $]_{\text {plasma }}$ and reduced renal excretion of chloride, which theoretically increases [SID] $]_{\text {urine }}$ and influences urine pH (Constable et al. 2009). Reduced fractional excretion of chloride occurs due to avidity for $\mathrm{NaCl}$ in dehydrated patients and the reduced glomerular filtration (Masevicius et al. 2010, Maciel et al. 2012). Additionally, urine potassium concentration has a profound effect on urine $\mathrm{pH}$, and when potassium deficiency occurs, renal potassium excretion is reduced and urine $\mathrm{pH}$ decreases, becoming acidic (Constable et al. 2009). The reduced serum potassium concentration and concomitant reduced FE of potassium observed in this study likely contributed to the reduction of urinary $\mathrm{pH}$, as described above.

Paradoxical aciduria occurs $60 \mathrm{~h}$ following duodenal obstruction (Gingerich \& Murdick 1975b). In our study, close care and monitoring by the farmer permitted early diagnosis and fast surgical intervention, which could explain the absence of acidic urine in G2. Surgical treatment returned flow through the abomasum and the metabolic alkalosis was reversed. These changes were reflected in the urine $\mathrm{pH}$, which increased until it reached normal physiologic values.

Establishing reference values for FE in cows with displaced abomasum could be a challenge. Beyond inter-individual variation (Lefebvre et al. 2008), there are significant variations in FE during the transition period (from two weeks pre-partum to four weeks postpartum) (Ulutaş et al. 2003), which is when the vast majority of abomasal displacements occur (Shaver 1997). Despite seasons and associated change of diet have influence in FE of electrolytes (Itoh 1989), this experiment was carried out in a short period of time, and the cows were fed the same feed throughout research period. Similarly, the FE did not differed according the period of lactation (Fleming et al.1992), however the potential weakness of this study was the high number of pregnant cows in G2, and consequently non-homogeneous groups, which may have influenced the results of FE, as showed in previous studies (Ulutaş et al. 2003).

Based on the study by Fleming et al. (1992), the FE of electrolytes in this study were almost all within the reference intervals. The absence of significant differences in FE during the experiment could be explained based on the time from diagnosis to treatment, as occurred with the urine $\mathrm{pH}$ and serum chloride concentration. The urinary excretion of chloride, sodium, and potassium usually decreases after 24, 24, and 72h, respectively (Gingerich \& Murdick 1975b).

\section{CONCLUSIONS}

The fractional electrolyte excretion (FE) and urinary SID are valuable tools for helping understand the hypochloremic, hypokalemic alkalosis that occurs in dairy cows with a displaced abomasum, as well as paradoxical aciduria.
These parameters supported the return of abomasal flux occasioned by both abomasopexy techniques, which was confirmed by acid-base status. Further studies in cows with a displaced abomasum are required.

\section{REFERENCES}

Baker J.S. 1976. Right displacement of the abomasum in the bovine: a modified procedure for treatment. Bovine Practice 11:58-60.

Balsorano P., Romagnoli S., Evans S.K., Ricci Z. \& De Gaudio A.R. 2016. Urinary strong ion difference as a marker of renal dysfunction: a retrospective analysis. PLoS One 11(6):e0156941. http://dx.doi.org/10.1371/journal. pone.0156941. PMid:27258049.

Barros Filho I.R. 2002. Perioperative veränderungen im säure-basen- und elektrolythaushalt von abomasopexierten oder omentopexierten kühen mit linksseitiger labmagenverlagerung. Dissertation, Tierärztliche Hochschule Hannover, Hannover, Germany. 123p.

Buscher C. \& Klee W. 1993. Untersuchungen über den prä-und postoperativen Verlauf von pH-Wert und Netto-Säure-Basen-Ausscheidung im Harn von Kühen mit Labmagenverlagerung. Dtsch. Tierärztl. Wochenschr. 100(5):171 176. PMid:8319542.

Christiansen K. 2004. laparoskopisch kontrollierte operation des nach links verlagerten labmagens (Janowitz-Operation) ohne ablegen des patienten. Tierärztl. Praxis 2:118-121.

Constable P.D., Gelfert C.C., Fürll M., Staufenbiel R. \& Stämpfli H.R. 2009 Application of strong ion difference theory to urine and the relationship between urine $\mathrm{pH}$ and net acid excretion in cattle. Am. J. Vet. Res. 70(7):915925. http://dx.doi.org/10.2460/ajvr.70.7.915. PMid:19566478.

DiBartola S.P. 2012. Metabolic acid-base disorders, p.253-286. In: Dibartola S.P. (Ed.), Fluid, Electrolyte and Acid-Base Disorders in Small Animal Practice. 4th ed. Saunders Elsevier, St Louis, Missouri. http://dx.doi.org/10.1016/ B978-1-4377-0654-3.00017-2.

Espinel C.H. 1976. The FENa test: use in the differential diagnosis of acute renal failure. J. Am. Med. Assoc. 236(6):579-581. http://dx.doi.org/10.1001/ jama.1976.03270060029022. PMid:947239.

Fleming S.A., Hunt E.L., Brownie C., Rakes A. \& McDaniel B. 1992. Fractional excretion of electrolytes in lactating dairy cows. Am. J. Vet. Res. 53(2):222 224. PMid:1575388.

Gardham J.R. 1970. Pyloric stenosis and paradoxical acid urine: an experimental study in dogs. Brit. J. Surg. 57(10):737. http://dx.doi.org/10.1002/ bjs.1800571010. PMid:5476750.

Gingerich D.A. \& Murdick P.W. 1975a. Paradoxic aciduria in bovine metabolic alkalosis. J. Am. Vet. Med. Assoc. 166(3):227-230. PMid:236990.

Gingerich D.A. \& Murdick P.W. 1975b. Experimentally induced intestinal obstruction in sheep: paradoxical aciduria in metabolic alkalosis. Am. J. Vet. Res. 36(5):663-668. PMid:237445.

González F.H., Hernández F., Madrid J., Martinez-Subiela S., Tvarijonaviciute A., Cerón J.J. \& Tecles F. 2011. Acute phase proteins in experimentally induced pregnancy toxemia in goats. J. Vet. Diagn. Invest. 23(1):57-62 http://dx.doi.org/10.1177/104063871102300108. PMid:21217028.

Itoh N. 1989. Fractional electrolyte excretion in adult cows: establishment of reference ranges and evaluation of seasonal variation. Vet. Clin. Pathol. 18(4):86-87. http://dx.doi.org/10.1111/j.1939-165X.1989.tb00524.x. PMid:15156506.

Kellum J.A. 2000. Determinants of blood pH in health and disease. Crit. Care 4(1):6-14. http://dx.doi.org/10.1186/cc644. PMid:11094491.

Koch S.M. \& Taylor R.W. 1992. Chloride ion in intensive care medicine. Crit. Care Med. 20(2):227-240. http://dx.doi.org/10.1097/00003246199202000-00012. PMid:1737457. 
Lefebvre H.P., Dossin O., Trumel C. \& Braun J.P. 2008. Fractional excretion tests: a critical review of methods and applications in domestic animals. Vet. Clin. Pathol. 37(1):4-20. http://dx.doi.org/10.1111/j.1939-165X.2008.00010.x. PMid:18366540.

Maciel A.T., Park M. \& Macedo E. 2012. Urinary electrolyte monitoring in critically ill patients: a preliminary observational study. Revta Bras. Terap. Intensiva 24(3):236-245. http://dx.doi.org/10.1590/S0103507X2012000300006. PMid:23917824.

Markusfeld 0. 1987. Aciduria in the postparturient dairy cow. Brit. Vet. J. 143(2):119-127. http://dx.doi.org/10.1016/0007-1935(87)90003-0. PMid:3580821.

Masevicius F.D., Tuhay G., Pein M.C., Ventrice E. \& Dubin A. 2010. Alterations in urinary strong ion difference in critically ill patients with metabolic acidosis: a prospective observational study. Crit. Care Resuscit. 12(4):248254. PMid:21143085

Masevicius F.D., Vazquez A.R., Enrico C. \& Dubin A. 2013. Urinary strong ion difference is a major determinant of plasma chloride concentration changes in postoperative patients. Revta Bras. Terap. Intensiva 25(3):197204. http://dx.doi.org/10.5935/0103-507X.20130035. PMid:24213082.

McGuirk S.M. \& Butler D.G. 1980. Metabolic alkalosis with paradoxic aciduria in cattle. J. Am. Vet. Med. Assoc. 177(6):551-554. PMid:7440350.
Moviat M., Pickkers P., Van der Voort P.H.J. \& Van der Hoeven J.G. 2006. Acetazolamide-mediated decrease in strong ion difference accounts for the correction of metabolic alkalosis in critically ill patients. Crit. Care 10(1):R14. http://dx.doi.org/10.1186/cc3970. PMid:16420662.

Neiger R.D. \& Hagemoser W.A. 1985. Renal percent clearance ratios in cattle. Vet. Clin. Pathol. 14(1):31-35. http://dx.doi.org/10.1111/j.1939-165X.1985. tb00843.x. PMid:15221690.

Shaver R.D. 1997. Nutritional risk factors in the etiology of left displaced abomasum in dairy cows: a review. J. Dairy Sci. 80(10):2449-2453. http:// dx.doi.org/10.3168/jds.S0022-0302(97)76197-6. PMid:9361217.

Siow S.L., Wong C.M. \& Sohail M. 2009. Adult pyloric stenosis masquerading as acute renal failure. Med. J. Malaysia 64(2):168-169. PMid:20058581.

Ulutaş B., Özlem M.B., Ulutaş P.A., Eren V. \& Paşa S. 2003. Fractional excretion of electrolytes during pre- and postpartum periods in cows. Acta Vet. Hung. 51(4):521-528. http://dx.doi.org/10.1556/AVet.51.2003.4.10. PMid:14680064.

Van Winden S.C.L. \& Kuiper R. 2003. Left displacement of the abomasum in dairy cattle: recent developments in epidemiological and etiological aspects. Vet. Res. 34(1):47-56. http://dx.doi.org/10.1051/vetres:2002060. PMid:12588683. 